О. І. Крижанівська

\title{
ОСОБЛИВОСТІ КОНТРОЛЬНИХ ЗАХОДІВ ПРИ ВИВЧЕННІ ІСТОРИЧНОЇ ГРАМАТИКИ ЗА КРЕДИТНО-МОДУЛЬНИМИ ПІДХОДАМИ
}

\begin{abstract}
Крижанівська О. І. Особливості контрольних заходів при вивченні історичної граматики за кредитно-модульними підходами.

У статті запропоновано авторський підхід до здійснення контролю за якістю знань студентів 3 історичної граматики української мови, коли вона викладається за змістовими модулями. Наводяться зразки контрольних робіт з історичної морфології.

Ключові слова: історична граматика, змістовий модуль, контрольні рівні (відтворення, розрізнення, умінь, інтерпретаціі).

Крижановская О. И. Особенности контрольных мероприятий при изучении исторической грамматики по кредитно-модульной системе.

В статье предложено авторское видение контроля качества знаний студентов по исторической грамматике украинского языка при её изучении за тематическими модулями. Предлагаются примеры контрольных работ по исторической морфологии.

Ключевые слова: историческая грамматика, тематический модуль, уровни контроля (воспроизведения, распознавания, умений, интерпретации).

Kryzhanivska O. I. Features of control measures when learning historical grammar with a creditmodular approach.

The article presents the author's approach to monitoring the quality of students' knowledge of historical grammar of the Ukrainian language taught by thematic modules. Examples of tests for historical morphology are suggested.

Key words: historical grammar, thematic module, control level (reproduction, differentiation, skills, interpretation).
\end{abstract}

Приєднання України до Болонських домовленостей спричинило низку проблем методичного характеру у викладанні всіх вишівських дисциплін, навіть таких класичних, як мовознавчі історичні. Вони завжди посідали особливе місце серед навчальних курсів підготовки філологів, оскільки вимагали добрих знань сучасної мови, уміння сконцентровувати увагу на доволі складному матеріалі, який передбачав здатність лінгвістично мислити, уявляти мовні процеси в їхньому розвитку i встановлювати причинно-наслідкові зв'язки мовних видозмін. Серед історичних лінгвістичних дисциплін згідно 3 навчальними планами підготовки фахівців за спеціальністю «Українська мова та література» ядерну позицію займає історична граматика української мови, на яку відводиться найбільша кількість годин і яка передбачає підсумкову атестацію у вигляді екзамену. Це й не дивно, адже тільки історія мови вчить, що «будь-які явища і факти потрібно розглядати на всіх етапах розвитку в їх взаємозв'язках, що дозволяє бачити їх не статично, а в історичній перспективі [1, с. 4]. Перспективність мислення - одна 3 провідних характеристик сучасного фахівця з вищою освітою. Саме тому в методиці вищої школи все більше уваги приділяють формуванню компетентнісних параметрів фахової досконалості. Особливо важливо це в 
підготовці майбутніх учителів, які згодом і самі будуть навчати не тільки фізики чи математики, мови чи літератури, а й мислити. Тому все частіше натрапляємо на твердження про те, що «суть підготовки педагогічних кадрів полягає не у збагаченні тих, хто навчається, певною кількістю інформації, а в розвитку уміння оперувати інформацією, проектувати та моделювати свою діяльність» [3].

Місце історичної граматики в системі мовознавчих дисциплін фахового блоку потребує переосмислення в новітні часи. По-перше, зведення його ролі тільки як до ілюстратора фактів сучасної української мови $\epsilon$ поверховим i не єдиним, адже розвивальний потенціал курсу надзвичайно багатий. По-друге, немає достатньо обгрунтованого бачення позиції історичної граматики у структурно-логічній схемі підготовки філолога, а це дозволяє деканатам вільно переставляти навчальну дисципліну 3 курсу на курс, переносити із семестру в семестр, що не сприяє повноцінному використанню здобутих знань, а, отже, створює враження непотрібності, певної ізольованості, осібності. По-третє, майже повна відсутність спеціальних періодичних видань мовно-методичного характеру для вищої школи не дозволяє обмінюватися методичними знахідками, не сприяє виробленню єдиної загальноукраїнської концепції викладання історичної граматики. По-четверте, серйозною проблемою залишається забезпечення вишів достатньо апробованими підручниками та навчально-методичними посібниками, збірниками вправ та іншим дидактичним матеріалом. Саме тому наукові конференції залишаються чи не єдиним дискусійним майданчиком для викладачів історичних мовних дисциплін, на якому можна обговорити 3 колегами актуальні питання методики викладання, з'ясувати суперечливі теоретичні моменти, поділитися практичними знахідками.

Пропонована стаття присвячена проблемі контролю якості знань за результатами осягнення студентом змістового модуля «Історична морфологія». Вибір модуля є довільним, оскільки нас цікавить передусім не певна тема, а форма і структура контрольного заходу по їі завершенні. Вирішення такого питання $є$ невеликою частиною формування сучасного освітнього середовища у вищій школі, воно ставиться в контексті «модернізації змісту освіти, створення системи моніторингу їі якості» [2, с. 1]. Актуальність постановки питань моніторингу якості знань загострилася в останній час, коли частина вчителів у середній школі і викладачів у вищій часто віддають перевагу тільки тестовим за формою контрольним роботам. Не заперечуючи самого факту зручності використання тестів при замірах залишкових знань, уважаємо, що підсумкова контрольна робота повинна носити комплексний характер і за формою, і за очікуваним результатом: вона обов'язково повинна показати не тільки те, що вивчив учень / студент, а й продемонструвати якісні параметри таких знань. Для цього пропонуємо контрольну роботу на чотири рівні такої структури: 
Перший рівень - рівень відтворення знань. На ньому пропонуються завдання, які передбачають відтворення вивченого. Це можуть бути дефініції, наведення конкретних фактів за вимогою тощо. Наприклад, дайте тлумачення поняття «зовнішня граматична аналогія», проілюструйте його прикладом з історії витворення відмінкових закінчень іменників другої відміни.

Другий рівень - рівень розрізнення контрольних одиниць. Передбачає уміння порівнювати, знаходити спільне й відмінне в контрольних одиницях, вибирати, групувати. Наприклад, виберіть із групи запропонованих дієслів іменні форми: несучи, читаль есмь, печи, носити, могль, ходити иму. Вкажіть назву іменної дієслівної форми.

Третій рівень - рівень практичних умінь і навичок фахового рівня. Тут перевіряється здатність студента робити різні види мовних розборів 3 урахуванням хронології тих чи тих змін, постання чи зникнення певних мовних явищ тощо. Наприклад, зробіть морфологічний аналіз усіх слів повнозначних частин мови із речення.

Четвертий рівень - рівень інтерпретації. Очікується вияв здатності узагальнювати, коментувати ті чи ті зміни, послуговуючись напрацюваннями класичного i сучасного мовознавства. Наприклад, доведіть або спростуйте думку про те, щь илях уодноманітнення граматичних форм став провідним при перебудові іменникової системи відмінювання. Підкріпіть свої твердження ичитуванням думок із авторитетних мовознавчих розвідок, вказавши найвідоміших дослідників становлення системи іменникового відмінювання.

Наводимо зразок одного 3 варіантів контрольної роботи, яка структурована чотирма рівнями.

Підсумкова контрольна робота зі змістового модуля «Історична морфологія»

Рівень 1(відтворення). Дайте відповіді на питання або продовжте речення, наведіть, де це можливо, приклади.

1. Назвіть і проілюструйте прикладами шляхи вдосконалення граматичної системи мови

2. Зовнішня аналогія виявляється в

3. Назвіть усі старі типи відмінювання іменників:

4. Граматичні ознаки коротких прикметників:

5. Займенники 3-ої особи витворилися 3

6. Неособові дієслівні форми

7. Відчислівникові прислівники

8. 8.1. детермінатив -

8.2. атематичні дієслова -

8.3. плюсквамперфект

Рівень 2 (розпізнавання)

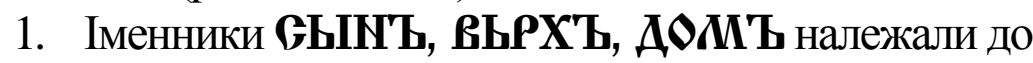



А)* -о̆- основи;
Б) *-ја- основи;
В) *-ŭ- основи;
Г) *-s- основи;
Д) *-і- основи.

2. Іменники І відміни GßЕКРУХА, КНЯГИНЯ, ПОЛОВИНА належали до
А)*-о̆- основи;
Б) *-ја- основи;
В) *-ŭ- основи;
Г) *-s- основи;
Д) різних основ.

3. ЕТОЛА, МЕАОУ, ГОАОУБИ - це форми
А) Р. в. однини;
Б) Д. в. однини;
В) Р. М. в, двоїни;
Г) Н. в. множини;
Д) різних відмінків.

4. В сучасній українській мові закінчення -у(-ю), -а(-я) в Р. в. одн. ім. чол. р. маємо внаслідок
А) витворення категорії істот / неістот;
Б) упливу середнього роду на чол.;
В) упливу ж. р. на чол.
Г) важко пояснити;
Д) змішання колишніх -о̆- та -й- основ.

Увага!!! Правильну відповідь на питання 5 формуєте шляхом добору відповідей з банку даних:
А) *-ŏ-, -јо̆- основи;
Б) *-a-, -ја- основи;
В) *-ŭ- основи;
Г) *-i- основи.
Д) $*$-й- основи
Е) *-s- основи;
E)*-t- основи;
Ж)*-n- основи;
3) *-r-основи.

5. ІІ відміна іменників СУЛМ сформувалася зі старих відмін:

6. Знайдіть відповідності:

6.1. Вказівні займенники

6.2. Означально-вказівні(анафористичні)

6.3. Означальні

6.4. Присвійні

6.5. Питальні, відносні

6.6. Заперечні
A) собъt, в $\mathbf{6}$

Б) кьжьдь, самъ, вьсь

В) нЊккьто, нъчььто

Г) вашь,свои

Д) сикь, тои , онь

Е) никьто, никыи 

6.7. Неозначені
Є) и, к, га
6.8. Особові
Ж) чьто, котрь

7. АОБРУЕМУ - це форма
А) членного стягненого прикметника;
Б) нечленного прикметника в Р. в. одн.
В) Н.-К. в. двоїни;
Г) Д. в. однини чол. роду;
Д) інша відповідь.

8. За допомогою суфікса -jes- творилися форми вищого ступеня
А) Н.-3. однини прикметників середнього роду;
Б) Н.-3. в, однини прикметників чоловічого роду;
В) Н.-3. в. однини прикметників жіночого роду;
Г) Н.-3. в. однини прикметників чол. і середнього роду;
Д) прикметників усіх родів і у всіх відмінках.

9. Числівники відмінювалися
9. 1. ДЬВА
А) як іменники на приголосний у множині;
9. 2. ТРИЕ
Б) як іменники в двоїні;
9.3. ЧСТБІРЕ
В) як іменники- i-основ у множині;
Г) як вказівні займенники
Д) за одним типом.

10. Остаточне оформлення числівника як окремої частини мови відбулося
А) у праслов'янській мові;
Б) у протоукраїнський період;
В) у староукраїнський період;
Г) у середньоукраїнський період;
Д) триває й досі.

11. Особовими дієслівними формами у староукраїнській мові були
А) інфінітив;
Б) перфект;
В) умовний спосіб;
Г) дієприкметник;
Д) аорист.

12. Знайдіть відповідності

12. 1.ДАВАЛЫ СУТЬ
А) 1 майбутній;
Б) супін;
В) плюсквамперфект;
Г) імперфект;
Д) перфект.

12. 2. ИМУ ДАВАТИ

12.3. ДАВАЛА БЪАХЬ

12. 4.ДАВААХЬ

12. 5.ДАВАТЬ

13. Знайдіть відповідності
13. 1. Аорист
13. 2. Імперфект
13. 3. Перфект
13. 4. Плюсквамперфект

А) походить із 1 майбутнього;

Б) занепав у кінці XII - поч. XIII ст.

В) занепав у XIV ст.

Г) перетворився в сучасн. мин. час; 
13. 5. Форма майбутнього синтетичного Д) залишився як складена форма

14. Активні нечленні дієприкметники теперішнього і минулого часу в СУЛМ
А) існують зараз у повному складі;
Б) частково втратилися;
В) повністю втратилися як окремі лексеми;
Г) перейшли в розряд дієприслівників;
Д) перейшли в прикметники.

15. Активні членні дієприкметники теперішнього часу в СУЛМ
А) існують зараз у повному складі;
Б) значною мірою втратилися;
В) повністю втратилися як окремі лексеми;
Г) перейшли в розряд дієприслівників;
Д) перейшли в прикметники.

16. Знайдіть відповідності
16. 1. къде
А) відіменниковий
16. 2. шкода
Б) відчислівниковий
16.3. двоичи
В) віддієслівний
16. 4. дочиста
Г) відзайменниковий
16. 5. нехотя
Д) відприкметниковий

Рівень 3 (умінь та навичок). Виконайте завдання

1. Покажіть шлях витворення таких українських слів:

Мала (прикм.)

п'ятнадцять

возитиму

2. Поставте давньоукраїнські іменники в заданій відмінковій формі, прокоментуйте витворення сучасних закінчень

ВОЛЬ

$$
\text { Р.в. Д.в. }
$$

ДРУГЬ

СТЕПЬ

3. Надпишіть частиномовну належність, вкажіть старий i новий типи відмінювання іменників, форми дієслів, прикметників, розряди займенників. Виділене слово розберіть морфологічно.

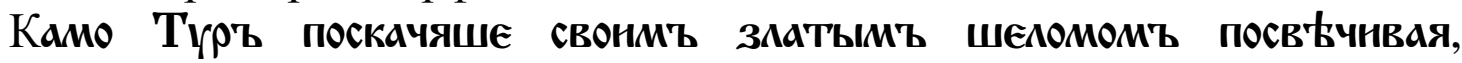
Тамо пеЖаТЬ ПоГаныя ГОловЫ ПОловецКЫЯ

Рівень IV (інтерпретаціi)

Доведіть або спростуйте думку про те, що давньоукраїнський дієприкметник став джерелом витворення нових дієслівних форм i поповнення інших морфологічних класів слів новими словами.

Література

[Жовтобрюх М. А., Волох О. Т., Самійленко С. П., Слинько І. І.]. - К. : «Вища школа», 1980. - 318 с.

2. Компетентнісний підхід у сучасній освіті: світовий досвід та українські перспективи / [під. заг. ред. О. В. Овчарук]. - К. : «К.І.С.», 2004. - 112 с. - (Бібліотека освітньої політики).

3. Тархан Л. З. Компетентнісний підхід до створення професійно-педагогічних програм підготовки інженерів-педагогів [Електронний ресурс]. - Режим доступу до тексту: http:// vuzlb.com/ content/view/293/84/ 